Journal of Finance Research

https://ojs.s-p.sg/index.php/jfr

\title{
Impact of Sino-US Trade Agreement on Chinese Legal System about Intellectual Property Rights
}

\section{Ting Liu*}

Sichuan Lvkeqin Law Firm, Chengdu, Sichuan, 610042, China

\begin{tabular}{l}
\hline ARTICLE INFO \\
\hline Article history \\
Received: 15 May 2020 \\
Revised: 22 May 2020 \\
Accepted: 9 October 2020 \\
Published Online: 16 October 2020 \\
\hline
\end{tabular}

Keywords:

Sino-US trade agreement

Chinese legal system

Tntellectual property rights

\section{Introduction}

$\mathrm{E}$ conomic and Trade Agreement Between the Government of the People's Republic of China and the Government of the United States of America (hereinafter referred to as Agreement) as the result of the first negotiation of Sino-US trade war focuses on the following fields: intellectual property rights, trade of agricultural products, financial market opening, etc., in which both China and America haggle over details of the surprising rich contents. The impact and challenge of the clauses of this Agreement to China's current legal system are discussed by starting from specific contents in the intellectual property rights field, without unnecessary details to the causes and background about the Sino-US trade war.

Since the dispute in the intellectual property rights field is always one of Sino-US trade dispute cores, the government of China constantly reinforces the crackdown

\section{ABSTRACT}

On January 15, 2020, the representatives of Sino-US trade signed Phase I Economic and Trade Agreement Between the Government of the People's Republic of China and the Government of the United States of America in Washington, which symbolizes the temporary settlement of two-year Sino-US trade war in relatively peaceful method and lays a good foundation in mutual trust for subsequent Phase II negotiation. This Agreement includes eight chapters involving Sino-US economic and trade and is called the model of the international bilateral agreement by virtue of its wide field and rigorous details. The impact of clauses about intellectual property rights on China's current legal system and the future revision direction of China's relevant laws for conformance with the Agreement will be discussed emphatically so that the author can rapidly understand the impact and significance of Sino-US trade agreement to Chinese law.

of its misappropriation act. Besides, the Sino-US trade agreement starts from the intellectual property rights to show its importance. The Parties specify the trade secrets protection, drug registration and patent protection term extension, copyright misappropriation of E-commerce platform, geographical indication, judicial proceedings and enforcement of intellectual property rights, etc. in details, with analyzed and interpreted as follows.

\section{Expansion of Trade Secret Misappropri- ation, Punishment Object in Agreement and Misappropriation Form}

In Article 1.3 (2) hereof, "China shall define 'operators' in trade secret misappropriation to include all natural persons, groups of persons, and legal persons." ${ }^{[1]}$, while in Article 2 of Law of the People's Republic of China on Anti-Unfair Competition, “'A business operator' mentioned

*Corresponding Author:

Ting Liu,

Master of Civil Law and Commercial Law;

Room 601, No. 64, Kehua North Road, Wuhou District, Chengdu City, Sichuan Province, 610042, China;

E-mail:359152369@qq.com. 
in this Law refers to a natural person or legal person or unincorporated organization engaged in commodities marketing or profit-making services ("commodities" used hereinafter includes such services)." The infringers in trade secret misappropriation include all natural persons, legal persons, and unincorporated organizations, instead of being confined to the particular entity engaged in economic activities and services.

In addition to that, Article 9 of Law of the People's Republic of China on Anti-Unfair Competition clearly states the form of trade secret misappropriation. In contrast, Article 1.4 hereof shows The Parties shall enumerate three additional acts constituting trade secret misappropriation, especially the electronic intrusions, breach or inducement of a breach of confidential obligation, and unauthorized disclosure or use of the Party in charge of protecting trade secret. Both of them indicate the above three kinds of methods still exist in the trade secret misappropriation field widely. Hence, the government of China shall also focus on the trade secret misappropriations even after extraordinary effort in the crackdown of them.

\section{Explanation of Expanded Protection Scope of Trade Secrets}

In Article 9 of Law of the People's Republic of China on Anti-Unfair Competition, "the 'trade secrets' as mentioned in this Law refer to any technology information or business operation information which is unknown to the public, can bring about economic benefits to the right holder, have practical utility and about which the right holder has adopted secret-keeping measures" ${ }^{[2]}$, while this Agreement specifies expansion of protection scope, including both traditional trade secret and confidential business information and shows that "The Parties agree that the term 'confidential business information' concerns or relates to the trade secrets, processes, operations, style of works, or apparatus, or to the production, business transactions, or logistics, customer information, inventories, or amount or source of any income, profits, losses, or expenditures of any natural or legal person, or other information of commercial value, the disclosure of which is likely to have the effect of causing substantial harm to the competitive position of such person from which the information was obtained."

The above definitions show the trade secrets belong to, and even a small part of confidential business information, with nonequivalence relation. Undoubtedly, the protection scope of trade secrets is significantly expanded after this Agreement was signed. China's current legal system will face enormous challenges if trade secrets are protected based on the definition of confidential business information. Not only would massive judicial resources be invested, but also, more importantly, excessive protection will severely impede business innovation and progress. Since confidential business information only occurs in annotation and Article 1.9 other than other parts which only mention trade secret, it is to be further discussed that confidential business information is only protected in specific fields. Chinese Law Circle shall focus on concerning the relationship between trade secrets and confidential business information herein and the confirmation of the scope of implementation of confidential business information legislation.

\section{Reversion of Burden of Proof in Civil Pro- cedure Case about Trade Secrets Misappro- priation}

In Article 1.5 (1) herein, "The Parties shall provide that the burden of production of evidence or burden of proof, as appropriate, shifts to the accused party in a civil judicial proceeding for trade secret misappropriation where the holder of a trade secret has produced prima facie evidence, including circumstantial evidence, of a reasonable indication of trade secret misappropriation by the accused party", and Article 1.5 (2) specifies the specific circumstantial evidence provided by China. Simply speaking, plaintiff, without enough direct proof in the verification of defendant's misappropriation act, can still file a lawsuit to court by virtue of the relevant circumstantial evidence showing the defendant may infringe trade secrets, and the defendant shall present evidence to verify the nonperformance of trade secrets misappropriation or the invalidation of plaintiff's trade secrets. In China, the general rule of burden of proof specifies who proposes shall present evidence, and the reversion of the burden of proof shall be expressly stipulated in laws ${ }^{[3]}$. The change of the burden of proof herein directly reduces the litigation threshold of civil procedure about trade secrets misappropriation. So China's civil procedure law system shall be adjusted accordingly as per the above contents hereof in the future legislation, and shall further interpret and stipulate the specific contents and scope of application about "circumstantial evidence" in details.

\section{Provisional Measures Increased for Protec- tion of Trade Secrets}

In Article 1.6 (2) herein, "China shall identify the use or attempted use of claimed trade secret information as an 'urgent situation' that provides its judicial authorities the authority to order the grant of a preliminary injunction 
based on the specific facts and circumstances of a case." Although The Civil Procedure Law of the People's Republic of China and relevant judicial interpretation clearly specify the "pre-litigation act injunction " and "in-litigation act injunction" earlier, local courts still give an excessively conservative verdict in the actual execution of pre-litigation act injunction due to its more abstraction than property preservation, non-directly measurable economic losses, etc. The pre-litigation act injunction is deemed as the most urgent and most essential relief means for the right holder in trade secrets case for the right holder's trade secrets couldn't be protected effectively under the invalid system. Besides, in allusion to the sharp reduction of procedure cost due to change of the burden of proof as mentioned above, a set of perfect quantitative consideration mechanisms with strong operability shall be established for the pre-litigation act injunction to avoid right holder from abusing litigation rights to attack competitors. To sum up, such clauses are of decisive significance in promoting the perfection of the pre-litigation act injunction system from a certain perspective in China's civil procedure.

\section{Significant Changes in Crime Standard of Loss Calculation Method of Trade Secrets Criminal Case}

In Article 1.7 (1) herein, "The Parties shall eliminate any requirement that the holder of a trade secret establishes actual losses as a prerequisite to the initiation of a criminal investigation for misappropriation of a trade secret." And China, as an interim step, shall identify the "heavy loss" in existing provisions shall contain remedial measure costs, such as the cost for enterprise operation and planning or maintenance of computer or other systems' safety. Besides, Article (1.8) hereof requires China to encompass cases of trade secret misappropriation through theft, fraud, physical or electronic intrusion for an unlawful purpose, and the unauthorized or improper use of a computer system in the scope of a prohibited act. All of them generate a significant impact on China's criminal law and criminal justice.

Firstly, in Article 219 of Criminal Law of the People's Republic of China, whoever commits any of the following acts of infringing on business secrets and thus causes heavy losses to the right holder shall be sentenced to fixed-term imprisonment of not more than three years or criminal detention and shall also, or shall only, be fined; if the consequences are especially serious, he shall be sentenced to fixed-term imprisonment of not less than three years but not more than seven years and shall also be fined: ${ }^{[4]}$, and in China's relevant judicial interpretation, trade secrets right holder generates heavy loss if loss amount reaches over RMB 0.5 million. ${ }^{[5]}$ So the crime standard of trade secret misappropriation is based on the heavy losses incurred to trade secrets right holder with the loss amount of over RMB 0.5 million under the existing Chinese law. In other words, if the doer only obtains the right holder's trade secrets in improper means without disclosure, usage, or allowing others' usage, his act can't cause heavy losses to the right holder and doesn't constitute a crime. However, the Sino-US trade agreement changes that rule, which indicates that trade secret oblige, without any actual loss, can still require initiating criminal investigation procedure in the future trade secret misappropriation crime.

Secondly, Article 219 of Chinese criminal law shows that three kinds of trade secrets misappropriation methods require the infringer to obtain others' trade secrets or disclose, use or allow others to use the right holder's trade secrets, reflecting infringer fully "controls" right holder's trade secrets. However, Article 1.8 hereof stipulates that the criminal procedures and penalties shall be initiated for the trade secrets misappropriation as long as doer's act infringes trade secrets, even if the doer doesn't obtain others' trade secrets, doesn't disclose, use or allow others to use trade secrets. So, trade secrets are significantly protected in this Agreement, and the trade secrets misappropriation act can constitute the cause of initiating criminal procedures and penalties regardless of disclosure, use or allowance of others' usage. The pure obtaining of trade secrets also constitutes the trade secrets misappropriation in accordance with the Sino-US trade agreement, which contradicts with mainstream opinion in Chinese academic circles $^{[6]}$.

Finally, two factors: the loss incurred to the right holder due to the misappropriation act and the benefit obtained by the right holder due to the misappropriation act shall be considered to identify the right holder's loss in current China's criminal justice practices. But in Article 1.7 (2) hereof agrees that the "heavy losses" can be fully shown by remedial costs. Hence, the calculation method of "heavy losses" of trade secrets misappropriation crime can be identified based on the remedial costs of trade secrets right holder, including the cost paid to reduce the damage to commercial operation or plan, the cost generated in guaranteeing computer or other systems' safety again, etc. And the operational and maintenance cost paid by the trade secrets right holder to remedy the misappropriation of trade secrets can be deemed as the calculation basis of "heavy loss", significantly reducing the burden of proof of trade secrets oblige. 


\section{Stricter Penalty for Infringement of Intel- lectual Property}

The infringement crimes of intellectual property in Article 213-219 of Criminal Law include the crime of counterfeiting the registered trademarks, the crime of selling commodities bearing counterfeit registered trademarks, the crime of illegally manufacturing or selling illegally-manufactured registered trademark mark, the crime of counterfeiting paten, the crime of infringing copyright, the crime of selling pirated goods and crime of trade secret infringement, and their terms of imprisonment are generally not high, in which the crime of infringing copyright and crime of selling pirated goods and crime of trade secret infringement can only be sentenced to fixed-term imprisonment of not more than three years at most, and other crimes shall be sentenced to fixed-term imprisonment of not more than seven years at most. While in Article 1.27 (2) hereof, "China shall: (a) as an interim step, deter future intellectual property theft or infringements and strengthen the application of existing remedies and penalties by imposing a heavier punishment at or near the statutory maximum permitted under its laws related to intellectual property to deter intellectual property theft or infringements; and (b) as a subsequent step, increase the range of minimum and maximum pre-established damages, sentences of imprisonment, and monetary fines to deter future intellectual property theft or infringements." In other words, China shall improve damages for intellectual property infringement act, sentences of imprisonment, and punishment of fines of intellectual property in the future as per the Sino-US trade agreement, while China shall, as an interim step, impose a heavier punishment at or near the statutory maximum permitted for infringement behavior of an intellectual property. As a result, China's legal protection in intellectual property can be promoted to an unprecedented level.

\section{Extension to Pharmaceutical Registration and Patent Protection Duration}

China shall permit pharmaceutical patent applicants to rely on supplemental data to satisfy relevant requirements for patent application during the patent examination proceedings, patent review proceedings, and judicial proceedings. The applicants submitting primary materials to China can exercise the right of defense after applying for a pharmaceutical patent to China. If the applicants submitting original materials find drugs approved and listed in China or other countries, China shall notify the obliges or licensees that others are applying for patents so that the licensees can seek for the relief measures before accused of the product listing. China, at the request of the patent owner, shall extend the term of a patent to compensate for unreasonable delays occurring in granting the patent. Currently, the maximum term period for a patent right protected by China's patent law reaches 20 years ${ }^{[7]}$, which is bounded to be prolonged after signing of this Agreement due to China's compromise. Hence, the government of China will keep a delicate balance between patent protection and innovation development.

\section{Protection of Geographical Indications}

Geographical indications are separately enumerated in Section 6 of the intellectual property part to show American attention to it. Undoubtedly, the United States is far earlier than China in terms of protection of geographical indications and promulgated the convenient and effective protection mode in the Lanham Act. Besides, international society started protecting geographical indications over one hundred years ago, including the later Agreement on Trade-Related Aspects of Intellectual Property Rights (TRIPS) approved by World Trade Organization, then various countries in the world reach the consensus to geographical indications for protection of intellectual property; while, China still continuously improves the geographical indications system at present. Then this Agreement specifies both America and China shall keep geographical indications completely transparent and procedure fair. So we can judge the United States, based on its mature protection mode, aims to require China to offer equal protection.

In recent years, China has made rapid progress in the protection of geographical indications. Concerning transparency, National Intellectual Property Administration promulgated the announcement about the protection of geographical indications products for the first time on $\mathrm{Au}-$ gust 8,2018 , to gradually disclose protected information; concerning management subject, National Intellectual Property Administration replaces General Administration of Quality Supervision, Inspection, and Quarantine to uniformly manage national protection of geographical indications products; with regard to legal provisions, the Measures for the Protection of Foreign Geographical Indication Products promulgated by AQSIQ in 2016 was revised by National Intellectual Property Administration in No. 338 Announcement, which further perfects the procedural protection of foreign geographical indications products ${ }^{[8]}$, in the new Trademark Act, misleading registration and usage of trademarks with geographical indication are forbidden ${ }^{[9]}$; and in Implementing Regulations of the Trademark Act, geographical indications can be applied and registered as collective trademarks or certification 
trademarks.

Generally speaking, China continuously adjusts and perfects the protection of geographical indications with the development of time, while the United States hopes China to quicken the pace and further increase the protection of American geographical indications by simplifying the application, acceptance, review, approval requirements, etc., to adapt the Sino-US trade demand. So China always pays attention to balancing the right protection of foreign obliges in China in legislative and judicial practice.

\section{Other Aspects}

Many other details are stipulated in Chapter intellectual property hereof, which aren't introduced one by one due to limited space, mainly including (1) China shall provide enforcement procedures for E-commerce infringement case. China's law enforcement agencies shall rapidly take down infringing products. The right holders propose extending to 20 working days as the deadline to file a judicial or administrative complaint. (2) About software protection, "The Parties shall ensure that all government agencies and all entities that the government owns or controls install and use only licensed software." China shall employ qualified third parties not belonging to or affiliated to the government for annual audit within seven months after the validation of this Agreement and publish the audit results on the internet. So does the United States. (3) To strengthen trademark protection, the Parties shall ensure adequate and effective protection and enforcement of trademark rights, particularly against bad-faith trademark registrations. (4) Strengthen the protection of copyright. In the absence of the relevant proof, the person whose name is indicated as the author, producer, performer, or publisher of the work, performance, or phonogram in the usual manner is the designated right holder in such work, performance.

\section{Conclusion}

According to the first phase of the economic and trade agreement between China and the United States, a large number of laws and regulations will be revised or adjusted in the foreseeable future. These legal changes do not mean substantive concessions but are necessary steps for China to improve its legal system. Since China has reserved enough room for legal amendments in the process of formulating relevant laws, especially procedural laws, the revision of relevant laws in China will not shake the foundation of China's legal system and system, on the contrary, it may make China's legal norms denser.

In the field of protection of intellectual property, China shall thoroughly learn from the legal system of western developed countries such as America, etc. to perfect the legal norm of intellectual property. China far falls behind America in terms of the research and legislation technology of intellectual property. Hence, in allusion to the requirements proposed by America in this Agreement, China's legislative body shall modify and perfect legal system about intellectual property in accordance with internationally-accepted standards, and carry out scientific legislation and implement laws reasonably in combination with China's national conditions so that China can develop rapidly in the field of intellectual property protection, creating a fair and reasonable market environment.

\section{References}

[1] Economic and Trade Agreement Between The Government of The People's Republic of China and The Government of The United States of America, 2020.

[2] Law of the People's Republic of China on Anti-Unfair Competition, 2019.

[3] The Civil Procedure Law of the People's Republic of China, 2017.

[4] Criminal Law of the People's Republic of China, 2017.

[5] Interpretation of the Supreme People's Court and the Supreme People's Procuratorate about Several Law Application Problems of Transacting Case of Intellectual Property Infringement Crime, 2004.

[6] Zhang Mingkai, Criminal Law (Version V), Law Press, 2015.

[7] Patent Law of the People's Republic of China, 2008.

[8] Measures for the Protection of Foreign Geographical Indication Products, 2016.

[9] Trademark Law of the People's Republic of China, 2019. 